\title{
Antibiotic prescribing for acute infections in synchronous telehealth consultations: a systematic review and meta-analysis
}

Bakhit, Mina; Baillie, Emma; Krzyzaniak, Natalia; van Driel, Mieke;

Clark, Justin; Glasziou, Paul; Del Mar, Christopher

DOI: https://doi.org/10.3399/BJGPO.2021.0106

To access the most recent version of this article, please click the DOI URL in the line above.

Received 11 June 2021

Revised 20 August 2021

Accepted 24 August 2021

(C) 2021 The Author(s). This is an Open Access article distributed under the terms of the Creative Commons Attribution 4.0 License (http://creativecommons.org/licenses/by/4.0/). Published by BJGP Open. For editorial process and policies, see:

https://bjgpopen.org/authors/bjgp-open-editorial-process-and-policies

When citing this article please include the DOI provided above.

\section{Author Accepted Manuscript}

This is an 'author accepted manuscript': a manuscript that has been accepted for publication in BJGP Open, but which has not yet undergone subediting, typesetting, or correction. Errors discovered and corrected during this process may materially alter the content of this manuscript, and the latest published version (the Version of Record) should be used in preference to any preceding versions 
1 Antibiotic prescribing for acute infections in synchronous telehealth consultations: a systematic review and meta-analysis

Mina Bakhit, Emma Baillie, Natalia Krzyzaniak, Mieke van Driel, Justin Clark, Paul Glasziou, and Chris Del Mar

\begin{tabular}{|l|l|l|}
\hline Author name & Qualifications & Job title \\
\hline Mina Bakhit* & MBBCh, PhD & $\begin{array}{l}\text { Post-doctoral research fellow, Institute for Evidence-Based } \\
\text { Healthcare, Faculty of Health Sciences and Medicine, Bond } \\
\text { University }\end{array}$ \\
\hline Emma Baillie & BPharm(Hons) & $\begin{array}{l}\text { PhD candidate, Primary Care Clinical Unit, Faculty of } \\
\text { Medicine, The University of Queensland }\end{array}$ \\
\hline Krzyzaniak & PhD & $\begin{array}{l}\text { Post-doctoral research fellow, Institute for Evidence-Based } \\
\text { Healthcare, Faculty of Health Sciences and Medicine, Bond } \\
\text { University }\end{array}$ \\
\hline $\begin{array}{l}\text { Mieke van } \\
\text { Driel }\end{array}$ & MSc, PhD, MD, & $\begin{array}{l}\text { Emeritus professor of general practice, Primary Care Clinical } \\
\text { Unit, Faculty of Medicine, The University of Queensland }\end{array}$ \\
\hline Justin Clark & BA & $\begin{array}{l}\text { Senior information specialist, Institute for Evidence-Based } \\
\text { Healthcare, Faculty of Health Sciences and Medicine, Bond } \\
\text { University }\end{array}$ \\
\hline Paul Glasziou & PhD, FRACGP & $\begin{array}{l}\text { Professor of evidence-based medicine, Institute for } \\
\text { Evidence-Based Healthcare, Bond University, Robina }\end{array}$ \\
\hline Chris Del Mar & MD, FRACGP & $\begin{array}{l}\text { Professor of public health, Institute for Evidence-Based } \\
\text { Healthcare, Bond University, Robina }\end{array}$ \\
\hline
\end{tabular}

8

9 *Corresponding author:

10 Mina Bakhit, PhD

11 Institute for Evidence-based Healthcare,

1214 University Drive, Bond University,

13 Gold Coast, Queensland, Australia, 4226

14 Email address: mbakhit@bond.edu.au

15 Phone: +6175595 1333 


\section{Abstract}

2 Background

3 Antibiotic prescribing is a major concern that contributes to the problem of antibiotic resistance.

4

5 Aim

6 To assess the effect on antibiotic prescribing in primary care of telehealth (TH) consultations

7 compared to face-to-face (F2F).

8 Design and setting

Systematic review and meta-analysis of adult or paediatric patients with a history of a community acquired acute infection (respiratory, urinary, or skin and soft tissue). We included studies that compared synchronous $\mathrm{TH}$ consultations (phone or video based) to $\mathrm{F} 2 \mathrm{~F}$ consultations in primary care.

Methods

We searched PubMed, Embase, Cochrane CENTRAL (inception-2021), clinical trial registries and citing-cited references of included studies. Two review authors independently screened the studies and extracted the data.

\section{Results}

We identified 13 studies. The one small randomized controlled trial found a non-significant $25 \%$ relative increase in antibiotic prescribing in the TH group. The remaining 10 were observational studies but did not control well for confounding, and therefore at high risk of bias. When pooled by specific infections, there was no consistent pattern. The six studies of sinusitis - including one before-after study - showed significantly less prescribing for acute rhinosinusitis in TH consultations, whereas the two studies of acute otitis media showed a significant increase. Pharyngitis, conjunctivitis, and urinary tract infections showed not-significant higher prescribing in the TH group. Bronchitis showed no change.

\section{Conclusions}

The impact of telehealth on prescribing appears to vary between conditions with more increases than reductions. However, there is insufficient evidence to draw strong conclusions, and higher quality research is urgently needed.

Keywords: Anti-Bacterial Agents, Respiratory Tract Infections, Urinary Tract Infections, 
2 Acute infections are commonly treated with antibiotics adding to the problem of antibiotic 3 resistance. Due to the coronavirus pandemic (COVID-19), there was a shift towards remote 4 consultations to decrease the risk of infection and transmission. However, it is not clear if telehealth 5 consultations are contributing to antibiotic overuse or not. This study assessed the effect on 6 antibiotic prescribing in primary care of telehealth (TH) consultations compared to face-to-face (F2F) 7 for acute infections. The impact of telehealth on prescribing appears to vary between conditions 8 with more increases than reductions. However, there is insufficient evidence to draw strong 9 conclusions, and higher quality research is urgently needed. 
3 Antibiotic prescribing is a major concern that contributes to the problem of antibiotic resistance. ${ }^{1}$ In

4 Australia, more than $41 \%$ of the population received at least one antibiotic in 2017,2 and $80 \%$ of

5 antibiotic prescriptions occurred in primary care. ${ }^{3}$

6 In primary care antibiotics are frequently prescribed for self-limiting acute respiratory infections

7 (ARIs) such as; middle ear infections, acute bronchitis, and sore throat, ${ }^{4}$ where antibiotics have little

8 benefits ${ }^{5-8}$ and may cause harms (such as vomiting, diarrhoea and rash).

9 Before the coronavirus pandemic in 2019 (COVID-19), several strategies (such as delayed

10 prescribing) and campaigns (such as the Choosing Wisely campaigns) aimed to reduce antibiotic prescribing. In Australia antibiotics are usually prescribed in a face-to-face consultation with general practitioners. However, in the era of COVID-19, remuneration for telehealth was introduced and many clinicians have shifted to deliver patient care remotely to decrease the risk of transmission. This change in mode of delivery may influence prescribing.

A recent systematic review concluded that there is insufficient evidence for an impact of telehealth consultations on antibiotic prescribing. ${ }^{9}$ This review has several limitations, mainly related to the search strategy, including studies for both synchronous and asynchronous telehealth consultations, and the method of analysis of the included studies, hindering the interpretation of the impact of telehealth on antibiotic prescribing. Our systematic review focuses only on synchronous telehealth consultations- better comparable to face-to-face consultations, our search strategy included broader keywords and mesh terms to find any relevant studies, and with a more detailed analysis subgrouped by the different conditions.

In this systematic review we aimed to identify and synthesize studies that have assessed the effect of synchronous telehealth consultations on antibiotic prescribing compared to face-to-face clinical encounters.

\section{Methods}

This systematic review is reported following the Preferred Reporting Items for Systematic Reviews and Meta-Analyses (PRISMA) statement ${ }^{10}$. The protocol was developed prospectively and registered on the International prospective register of systematic reviews (PROSPERO) Registration number CRD42021239164. We followed the "2-week systematic review" (2weekSR) processes. ${ }^{11}$

\section{Eligibility criteria}

\section{Participants}

We included studies of adult or paediatric patients with a history of a community acquired acute infection (respiratory, urinary, or skin and soft tissue). We excluded studies of patients with chronic infections, or hospitalized patients.

\section{Interventions}

We included studies of any type of synchronous telehealth consultations (phone or video-based). Studies that reported the use of asynchronous telehealth consultations (text-based or web-based with automated feedback) were excluded. Studies with telehealth consultations combined with an education component were excluded unless it was given to both groups.

\section{Comparators}

44 We included studies that compared telehealth consultations to the usual face-to-face consultations. 
2 The primary outcome was the number of antibiotic prescriptions in each type of consultation.

3 The secondary outcomes were follow-up visit rates, testing rates or number of samples sent to the

4 laboratory, any reported adverse events, hospitalization, and associated costs.

\section{Study design}

7 We included randomized controlled trials of any design (e.g., parallel, cluster, crossover), and any

8 type of observational studies. Reviews of primary studies (e.g., systematic reviews, literature

9 reviews, etc.) were excluded.

\section{Search strategies}

\section{Database search}

We searched PubMed, Embase, Cochrane CENTRAL from inception until 23 February 2021. We designed the search string in PubMed, then translated it for use in the other databases using the Polyglot Search Translator. ${ }^{12}$ The complete search strings for all databases are provided in Supplementary Box 1.

Clinical trial registries were searched on 2 March 2021 via Cochrane CENTRAL, which includes the WHO International Clinical Trials Registry Platform (ICTRP) and clinicaltrials.gov. We also searched for preprint articles through the Europe PMC database.

On 1 March 2021, we conducted a backwards (cited) and forwards (citing) citation analysis in Scopus on the included studies identified by the database searches. These were screened against the inclusion criteria.

No restrictions by language or publication date were imposed. We included publications that were published in full. Publications available as abstract only (e.g., conference abstract) were included if they had a clinical trial registry record, or other public report, with the additional information required for inclusion. We excluded publications available as abstract only (e.g., conference abstract) unless additional information available.

\section{Study selection and screening}

Two review authors ( $\mathrm{MB}$ and $\mathrm{EB}$ or $\mathrm{NK}$ ) independently screened the titles and abstracts for inclusion against the inclusion criteria. One author (JC) retrieved full-text, and two authors (EB and NK) screened the full-texts for inclusion. Any disagreements were resolved by discussion, or reference to a third author (MB, MVD, CDM). The selection process was recorded in sufficient detail to complete a PRISMA flow diagram (see Figure 1) and a list of excluded (full text) studies with reasons for exclusions (Supplementary Table 1).

\section{Data extraction}

We used a data extraction form for study characteristics and outcome data, which was piloted on 2 studies in the review. Two authors extracted the following data from included studies:

- Methods: study authors, location, study design, duration of follow-up

- Participants: N, age (mean/median, range/SD), conditions, recent antibiotic use.

- Interventions: Type of telehealth consultation (video, phone, mixed, online), duration, who provided it, training, previous experience.

- Primary and secondary outcomes: indication for antibiotics, antibiotic prescribing rate, adverse events, number of follow-up visits, number of tests requested, or samples sent to the laboratory, hospitalization, antibiotic resistance (if measured in a follow-up visit).

45 
Assessment of risk of bias

2 Two authors ( $\mathrm{MB}$ and EB or NK) independently assessed the risk of bias for RCTs using the Cochrane

3 Risk of Bias Tool ${ }^{13}$ and for observational studies using ROBINS-I. ${ }^{14}$ We did not use the Newcastle-

4 Ottawa Scale as initially reported in our protocol, due to the lack of comprehensive manuals,

5 which meant that the tool instructions could be interpreted differently by different assessors. All

6 disagreements were resolved by discussion.

7

8 Measurement of effect and data synthesis

9 Review Manager 5.4 was used to calculate the treatment effect ${ }^{15}$. We used odds ratios for We undertook meta-analyses only when meaningful (when $\geq 2$ studies or comparisons reported the same outcome); anticipating considerable heterogeneity, we used a random effects model.

We separated analysis for RCTs, and observational studies (e.g., cross-sectional studies). We split our analysis by reported conditions (e.g., sinusitis, bronchitis). No studies reported the severity of the condition and thus we did not perform this subgroup analysis.

The individual was used as the unit of analysis, where possible. However, the data on the number of individuals with primary and secondary outcomes of interest was not available. We extracted the information as it was presented, e.g., the number of antibiotic prescriptions for all encounters/visits in each group.

We contacted the authors of all included cross-sectional studies to obtain data of antibiotic prescribing in previous years to control for any trend of change in antibiotic prescribing. However, the responding authors stated they were unable to provide this for a variety of reasons.

We used the $\mathrm{I}^{2}$ statistic to measure heterogeneity. As we only included one trial, we did not create a funnel plot.

\section{Results}

\section{Search results}

The searches across 3 databases yielded 650 records. A backwards (cited) and forwards (citing) citation analysis yielded an additional 433 records. The clinical registry search returned 19 records, and the preprint search via Europe PMC returned an additional 150, resulting in a total of 1067 records to screen after deduplication. We excluded 1011 records after title and abstract screening and obtained 56 records for full-text screening. We included 13 studies in the qualitative synthesis and the meta-analysis (Figure 1). See Supplementary Table 1 for a full list of excluded Studies with reasons for exclusion.

\section{Study characteristics}

Of the 13 included studies (Supplementary Table $\mathbf{2}^{16-28}$ ), all except two, were conducted in the United States of America (USA); they comprised 11 cross-sectional studies, ${ }^{16-18} 21-28$ one retrospective before-after study ${ }^{20}$ and just one RCT. ${ }^{19}$ Nine studies reported antibiotic prescribing for a respiratory infection only, two studies provided data for all acute infections (respiratory, urinary, and skin and soft tissue infections), one for both urinary and respiratory infections, and one for urinary infections 
only. We did not find any studies that reported on antibiotic prescribing in telehealth versus face-toface consultations for skin and soft tissue infections. The type of telehealth consultations varied; five studies reported the use of mixed phone and video consultation, four phone-only consultations, two video consultations, and the mode was not clearly reported in two studies.

Risk of bias assessment

For the only RCT identified, we used the Cochrane risk of bias tool- 1 to assess the risk of bias. ${ }^{19}$ The overall risk of bias was generally unclear. Blinding of the patients and health care providers was not possible. Random sequence generation, allocation concealment, blinding of outcome assessment and the conflict-of-interest statement were all unclear due to inadequate reporting in the trial. We found no evidence of incomplete outcome data or selective reporting of outcomes. The study funding was reported.

For the remaining 12 studies, using the ROBINS-I tool to assess the risk of bias, ${ }^{16-18} 20-28$ found the studies were mostly of moderate or serious risk of bias (Table 1). Due to the study designs, most studies were considered at serious risk of confounding, unless the study authors reported an appropriate analysis method used to adjust for important baseline confounding factors such as: age, severity of infection, and any reported co-morbidities. Most studies had serious bias for the selection of participants, as patients with less severe infections may differentially choose a mode of consultations (telehealth rather than face-to-face). No information was available for the reporting of missing data or selection of the reported results (no available protocols). The included studies had moderate or serious risk of bias in classification of interventions and reported deviations from intended interventions. Measurement of outcomes was rated 'moderate' for all studies.

\section{[Table 1]}

\section{Primary outcome: Antibiotic prescribing}

Randomized controlled trials $(n=1)$

Only one small trial investigated the difference of antibiotic prescribing between patients requesting same-day appointments managed by face-to-face consultation $(n=187)$ compared with telephone consultation ( $n=180) .{ }^{19}$ There was more, but not significant, antibiotic prescribing in the telehealth group compared to F2F consultations (Odds ratio (OR) $1.25,95 \% \mathrm{Cl} 0.73$ to 2.15 ) (Figure 2).

\section{Before-After study $(n=1)$}

One study examined antibiotic prescribing patterns after the transition to telehealth visits, due to COVID-19 pandemic, and compared it to the previous F2F visits for acute rhinosinusitis. ${ }^{20}$ There was significantly less antibiotic prescribing in telehealth consultations (OR $0.78,95 \% \mathrm{Cl} 0.69$ to 0.89 ) (Figure 2).

\section{Cross-sectional studies $(n=11)$}

Comparison of telehealth consultations with face-to-face in cross-sectional studies was sub-grouped into the type of reported condition, to reduce confounding of type of consultation by condition (Figure 2). 
1

2 There was higher, but not significant,
3 1.0). Heterogeneity was high (78\%).

4 Pharyngitis $(n=4)$

5 There was higher, but not significant, antibiotic prescribing in the telehealth group (OR $1.4,95 \% \mathrm{Cl}$

60.95 to 2.1 ). Heterogeneity was high (81\%)

7 Bronchitis $(n=3)$

8 There was no significant difference in antibiotic prescribing for patients with bronchitis (OR 0.98,

$995 \% \mathrm{Cl} 0.6$ to 1.6). Heterogeneity was high (90\%)

10 Acute otitis media $(n=2)$

There was significantly more antibiotic prescribing for patients with acute otitis media in telehealth consultations (OR $1.3,95 \% \mathrm{Cl} 1.11$ to 1.5 ), with no heterogeneity.

\section{Conjunctivitis $(n=2)$}

There was higher, but not significant, antibiotic prescribing in the telehealth group (OR $1.8,95 \% \mathrm{Cl}$ 0.7 to 4.5$)$. Heterogeneity was high (91\%).

Urinary tract infections $(n=2)$

There was higher, but not significant, antibiotic prescribing in the telehealth group (OR $1.4,95 \% \mathrm{Cl}$ 0.7 to 2.9$)$. Heterogeneity was high (79\%).

[Figure 2]

\section{Secondary outcomes}

Diagnostic tests performed

Table 2 shows the reported diagnostic tests performed after each type of consultation from six studies. Generally, there are fewer diagnostic tests performed with telehealth consultations compared to F2F.

\section{[Table 2]}

One study reported the percentage of adults who were diagnosed with pharyngitis and received an appropriate Group A Streptococcus (strep) test to confirm the diagnosis. ${ }^{28}$ The F2F group ( $n=2297$, $49.5 \%)$ performed better than the telehealth group $(n=4,3.4 \%)$ on appropriate testing for pharyngitis.

\section{Follow-up visits}

Seven studies provided results of follow-up visits (See Table 3). In general, patients who were initially evaluated through phone contact were more likely to receive follow-up. The studies show 
different follow-up time points.

\section{[Table 3]}

Adverse events (AE)

One study reported no statistically significant difference in the reported adverse events as evaluated by diagnosis of pyelonephritis within 30-day follow-up duration for patients with urinary tract infections. ${ }^{21}$ The study reported no hospitalization or sepsis in any patients for both F2F and telehealth encounters (Supplementary Table 3).

\section{Discussion}

\section{Summary of findings}

Our review identified only one RCT that assessed the impact of telehealth compared with face-toface consultations on antibiotic prescribing: finding a non-significant $25 \%$ relative increase. Most studies were observational, did not control well for confounding, and therefore were prone to bias. Pooling observational studies does not show a consistent pattern when analysed for specific infections. For instance, antibiotic prescribing for acute sinusitis may be higher in a F2F consultation and for pharyngitis higher in telehealth. However, many effect estimates do not reach statistical significance and with significant heterogeneity suggesting, other than clinical differences, methodological issues within the included studies.

\section{Comparison with existing literature}

Our general finding is broadly consistent with the systematic review by Han et al ${ }^{9}$ who concluded there was insufficient evidence that telehealth consulting has a significant impact on antibiotic prescribing in primary care. However, in our review we pooled the observational studies and explored the impact in consultations concerning specific infections. These results show a more diverse picture that can make clinical sense. The two cross-sectional studies that assessed prescribing for acute otitis media ${ }^{25} 26$ consistently find that antibiotics are more likely to be prescribed in TH consultations. Perhaps the inability to examine the ear allows clinicians to be more lenient with prescribing, especially under parental pressure. ${ }^{29}$

\section{Strengths and weaknesses}

This review's main strength is its rigor of methods and analysis: the extensive search is unlikely to missed important studies; and the detailed synthesis of the results by study design and by condition has made best use of the available published research. However, there are also several weaknesses: the paucity of studies with adequate control of confounding; the wide heterogeneity (both of clinical conditions and results); and imprecision of the results, means that there is no single reliable message to take away from this research.

\section{Implications for research and clinical practice}

It is important to note there are different modalities of telehealth, with or without visual that may impact the inclination to prescribe. Also, the link with clinical outcomes and patient satisfaction 
deserves further exploration. ${ }^{30}$ In situations like the current COVID-19 pandemic, synchronous telehealth consultations have ensured patients' access to primary care services and have changed the landscape of service delivery for good. ${ }^{31}$ Therefore, better understanding how prescribing adapts is critical for antimicrobial stewardship.

While there is insufficient evidence about the rate of antibiotic prescribing in teleconferences compared to the usual face-to-face ones to draw strong conclusions, there are some concerns. The impact appears to vary between conditions, but more suggest increases in antibiotic than reductions. For example, if patients with acute respiratory infections all chose to consult via telehealth, then the antibiotic prescriptions for telehealth would be greater than face-to-face (and the reverse of those patients selectively chose face-to-face consultation). Furthermore, telehealth may change the diagnostic process because of the limitations on physical examination. Given the importance of any increased antibiotic use to the development of antibiotic resistance, ${ }^{32}$ this clearly this suggests more studies need to be undertaken with better design - either as randomized trials, or at least controlled before-after studies. To study prescribing change at population level, the ideal study process would be to compare the change in antibiotics when a blend of telehealth and face-toface consultations are introduced with the change of face-to-face is retained. In the situation when randomisation of practices is not possible, then we might adjust for confounding by using the prechange level of antibiotic prescribing, and ideally for any trends using a series of times prior to the change. If the suggestions that in some diagnoses more antibiotics are prescribed in F2F consultations, then further research to understand ameliorate will become urgent.

Funding: No funding or other material support was sought or received to perform this work specifically; however, one of the authors is recipient of funding from the National Health and Medical Research Council Centre for Research Excellence in Minimising Antimicrobial Resistance in the Community (CRE-MARC: GNT1153299), within whose remit the present review was conducted; 2 of the authors' salaries are partially funded by CRE-MARC and 2 of the authors' salaries are completely funded by CRE-MARC. The funder had no involvement in this systematic review.

Ethical approval: None required

Competing interests: None 


\section{References}

2

3

4

5

6

7

8

9

10

11

12

13

14

15

16

17

18

19

20

21

22

23

24

25

26

27

28

29

30

31

32

33

34

35

36

37

38

39

40

41

42

43

44

45

46

47

48

49

50
1. O'Neill J. Tackling drug-resistant infections globally: final report and recommendations. 2016

2. Australian Commission on Safety and Quality in Health Care (AURA) 2019: third Australian report on antimicrobial use and resistance in human health: ACSQHC Sydney.

3. Del Mar C, Glasziou P, Lowe JB, et al. Addressing antibiotic resistance - focusing on acute respiratory infections in primary care. Aust Fam Physician 2012;41(11):839-40. [published Online First: 2012/11/13]

4. McCullough AR, Pollack AJ, Plejdrup Hansen M, et al. Antibiotics for acute respiratory infections in general practice: comparison of prescribing rates with guideline recommendations. Med J Aust 2017;207(2):65-69. doi: 10.5694/mja16.01042 [published Online First: 2017/07/14]

5. Kenealy T, Arroll B. Antibiotics for the common cold and acute purulent rhinitis. Cochrane Database Syst Rev 2013(6):CD000247. doi: 10.1002/14651858.CD000247.pub3 [published Online First: 2013/06/05]

6. Smith SM, Fahey T, Smucny J, et al. Antibiotics for acute bronchitis. Cochrane Database Syst Rev 2014(3)

7. Spinks A, Glasziou PP, Del Mar CB. Antibiotics for sore throat. Cochrane Database Syst Rev 2013(11):CD000023. doi: 10.1002/14651858.CD000023.pub4 [published Online First: 2013/11/06]

8. Venekamp RP, Sanders S, Glasziou PP, et al. Antibiotics for acute otitis media in children. Cochrane Database Syst Rev 2013(1):CD000219. doi: 10.1002/14651858.CD000219.pub3 [published Online First: 2013/02/27]

9. Han SM, Greenfield G, Majeed A, et al. Impact of Remote Consultations on Antibiotic Prescribing in Primary Health Care: Systematic Review. J Med Internet Res 2020;22(11):e23482. doi: 10.2196/23482 [published Online First: 2020/10/09]

10. Moher D, Liberati A, Tetzlaff J, et al. Preferred reporting items for systematic reviews and metaanalyses: the PRISMA statement. PLoS Med 2009;6(7):e1000097. doi: 10.1371/journal.pmed.1000097 [published Online First: 2009/07/22]

11. Clark J, Glasziou P, Del Mar C, et al. A full systematic review was completed in 2 weeks using automation tools: a case study. J Clin Epidemiol 2020;121:81-90. doi: 10.1016/j.jclinepi.2020.01.008 [published Online First: 2020/02/01]

12. Clark JM, Sanders S, Carter M, et al. Improving the translation of search strategies using the Polyglot Search Translator: a randomized controlled trial. J Med Libr Assoc 2020;108(2):195207. doi: 10.5195/jmla.2020.834 [published Online First: 2020/04/08]

13. Higgins JPT, Green S. Cochrane Handbook for Systematic Reviews of Interventions. 1. Aufl. ed. Hoboken: Wiley 2008.

14. Sterne JA, Hernan MA, Reeves BC, et al. ROBINS-I: a tool for assessing risk of bias in nonrandomised studies of interventions. BMJ 2016;355:i4919. doi: 10.1136/bmj.i4919 [published Online First: 2016/10/14]

15. Review Manager (RevMan) [program]. Version 5.3. version. Copenhagen: The Nordic Cochrane Centre, The Cochrane Collaboration, 2014.

16. Davis CB, Marzec LN, Blea Z, et al. Antibiotic Prescribing Patterns for Sinusitis Within a Direct-toConsumer Virtual Urgent Care. Telemed J E Health 2019;25(6):519-22. doi: 10.1089/tmj.2018.0100 [published Online First: 2018/07/19]

17. Gordon AS, Adamson WC, DeVries AR. Virtual Visits for Acute, Nonurgent Care: A Claims Analysis of Episode-Level Utilization. J Med Internet Res 2017;19(2):e35. doi: 10.2196/jmir.6783 [published Online First: 2017/02/19]

18. Halpren-Ruder D, Chang AM, Hollander JE, et al. Quality Assurance in Telehealth: Adherence to Evidence-Based Indicators. Telemed J E Health 2019;25(7):599-603. doi: 10.1089/tmj.2018.0149 [published Online First: 2018/08/03] 
19. McKinstry B, Walker J, Campbell C, et al. Telephone consultations to manage requests for sameday appointments: a randomised controlled trial in two practices. Br J Gen Pract 2002;52(477):306-10. [published Online First: 2002/04/11]

20. Miller LE, Bhattacharyya N. Antibiotic Prescribing for Acute Rhinosinusitis: In-Person Versus Virtual Visits During Covid-19. Laryngoscope 2020 doi: 10.1002/lary.29323 [published Online First: 2020/12/10]

21. Murray MA, Penza KS, Myers JF, et al. Comparison of eVisit Management of Urinary Symptoms and Urinary Tract Infections with Standard Care. Telemed J E Health 2020;26(5):639-44. doi: 10.1089/tmj.2019.0044 [published Online First: 2019/07/18]

22. Norden JG, Wang JX, Desai SA, et al. Utilizing a novel unified healthcare model to compare practice patterns between telemedicine and in-person visits. Digit Health 2020;6:2055207620958528. doi: 10.1177/2055207620958528 [published Online First: 2020/10/01]

23. Penza KS, Murray MA, Myers JF, et al. Management of Acute Sinusitis via e-Visit. Telemed J E Health 2021;27(5):532-36. doi: 10.1089/tmj.2020.0047 [published Online First: 2020/06/12]

24. Penza KS, Murray MA, Myers JF, et al. Treating pediatric conjunctivitis without an exam: An evaluation of outcomes and antibiotic usage. J Telemed Telecare 2020;26(1-2):73-78. doi: 10.1177/1357633X18793031 [published Online First: 2018/08/30]

25. Ray KN, Shi Z, Gidengil CA, et al. Antibiotic Prescribing During Pediatric Direct-to-Consumer Telemedicine Visits. Pediatrics 2019;143(5) doi: 10.1542/peds.2018-2491 [published Online First: 2019/04/10]

26. Shi Z, Mehrotra A, Gidengil CA, et al. Quality Of Care For Acute Respiratory Infections During Direct-To-Consumer Telemedicine Visits For Adults. Health Aff 2018;37(12):2014-23. doi: 10.1377/hlthaff.2018.05091 [published Online First: 2019/01/12]

27. Stenehjem E, Wallin A, Fleming-Dutra KE, et al. Antibiotic Prescribing Variability in a Large Urgent Care Network: A New Target for Outpatient Stewardship. Clin Infect Dis 2020;70(8):1781-87. doi: 10.1093/cid/ciz910 [published Online First: 2019/10/24]

28. Uscher-Pines L, Mulcahy A, Cowling D, et al. Access and Quality of Care in Direct-to-Consumer Telemedicine. Telemed J E Health 2016;22(4):282-7. doi: 10.1089/tmj.2015.0079 [published Online First: 2015/10/22]

29. Hansen MP, Howlett J, Del Mar C, et al. Parents' beliefs and knowledge about the management of acute otitis media: a qualitative study. BMC Fam Pract 2015;16(1):82. doi: 10.1186/s12875-015-0297-7 [published Online First: 2015/07/08]

30. Kruse CS, Krowski N, Rodriguez B, et al. Telehealth and patient satisfaction: a systematic review and narrative analysis. BMJ Open 2017;7(8):e016242. doi: 10.1136/bmjopen-2017-016242 [published Online First: 2017/08/05]

31. Monaghesh E, Hajizadeh A. The role of telehealth during COVID-19 outbreak: a systematic review based on current evidence. BMC Public Health 2020;20(1):1193. doi: 10.1186/s12889-02009301-4 [published Online First: 2020/08/03]

32. Bakhit M, Hoffmann T, Scott AM, et al. Resistance decay in individuals after antibiotic exposure in primary care: a systematic review and meta-analysis. BMC Medicine 2018;16(1):126. doi: 10.1186/s12916-018-1109-4 


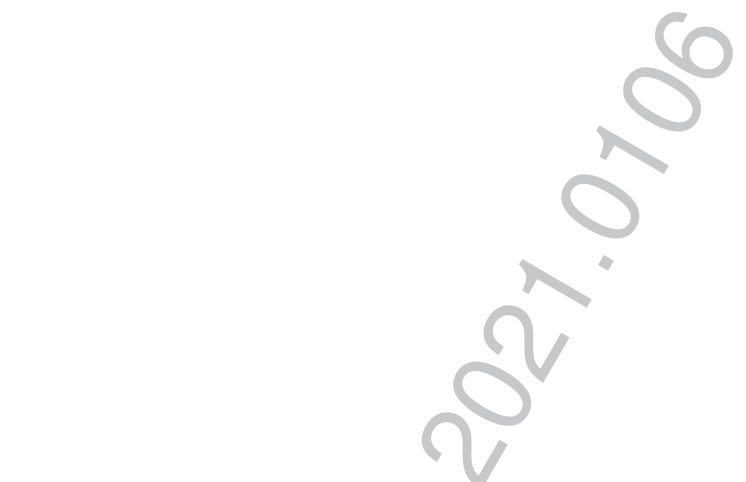

\begin{tabular}{|} 
Records identified through database \\
searching \\
$(n=650)$
\end{tabular}

Additional records identified through other sources

( $n=602$ )

6

Records after duplicates removed ( $n=1067$ )
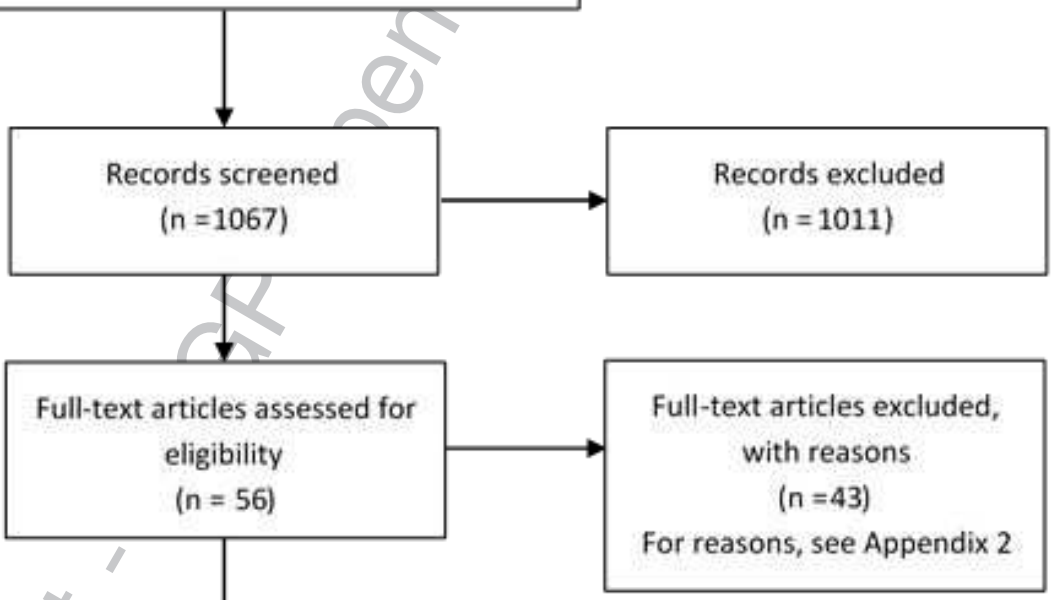

Studies included in qualitative synthesis and meta-analysis ( $n=13$ )

7

8

Figure 1. PRISMA Flow Diagram ${ }^{10}$

9 


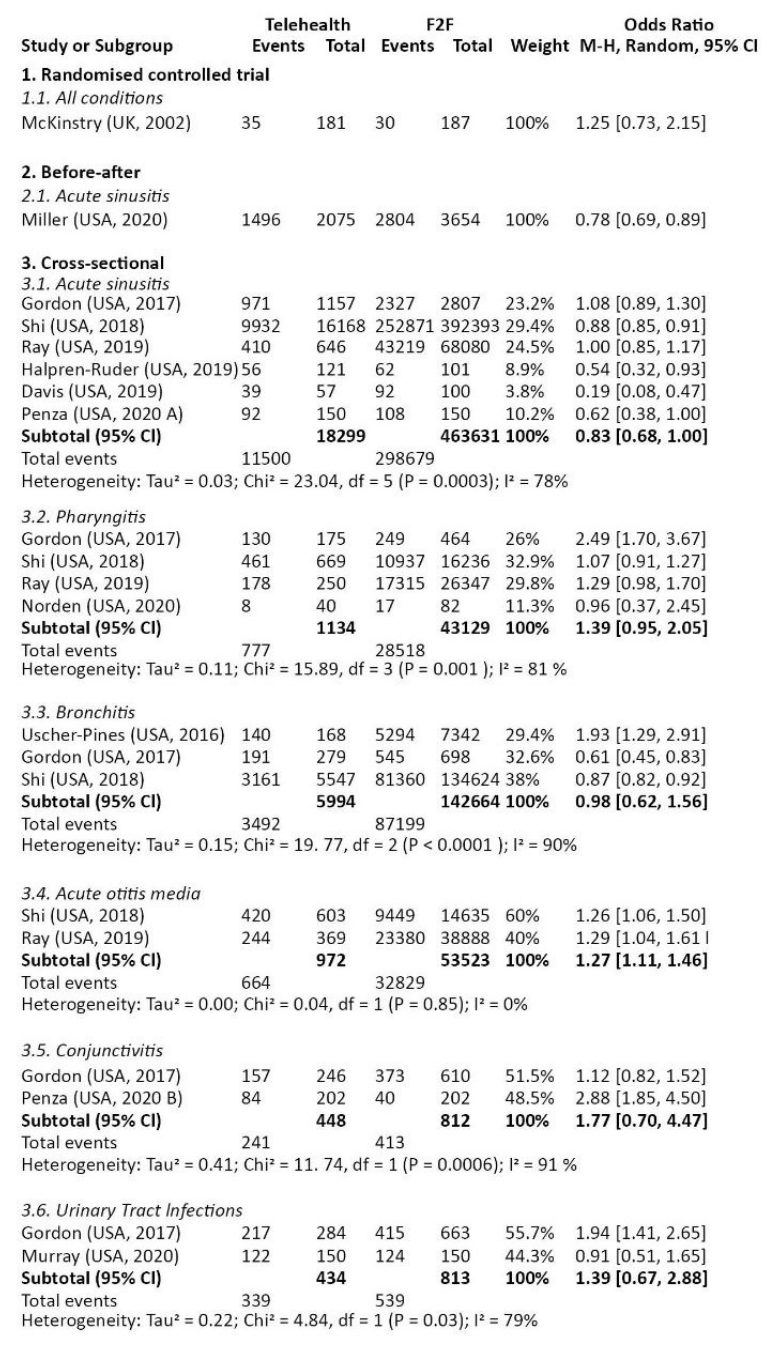

Odds Ratio

$\mathrm{M}-\mathrm{H}$, Random, $95 \% \mathrm{CI}$

1. Randomised co

.

McKinstry (UK, 2002)
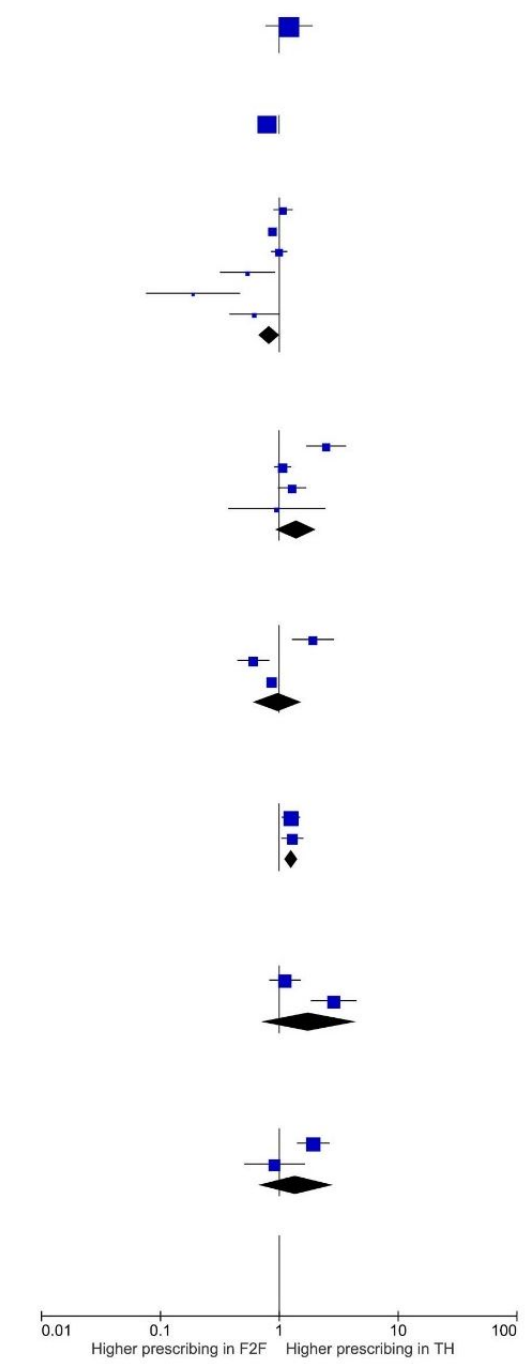

2 Figure 2. Antibiotic prescribing in synchronous telehealth compared to face-to-face (F2F)

3 consultations

4

5 
Table 1. Risk of bias of included observational studies using ROBINS-I

\begin{tabular}{|c|c|c|c|c|c|c|c|c|}
\hline Reference & $\begin{array}{l}\text { Bias due to } \\
\text { confounding }\end{array}$ & $\begin{array}{l}\text { Bias in } \\
\text { selection of } \\
\text { participants } \\
\text { into the } \\
\text { study }\end{array}$ & $\begin{array}{l}\text { Bias in } \\
\text { classification } \\
\text { of } \\
\text { interventions }\end{array}$ & $\begin{array}{l}\text { Bias due to } \\
\text { deviations } \\
\text { from } \\
\text { intended } \\
\text { interventions }\end{array}$ & $\begin{array}{l}\text { Bias due to } \\
\text { missing } \\
\text { data }\end{array}$ & $\begin{array}{l}\text { Bias in } \\
\text { measurement } \\
\text { of outcomes }\end{array}$ & $\begin{array}{l}\text { Bias in } \\
\text { selection of } \\
\text { the } \\
\text { reported } \\
\text { results }\end{array}$ & $\begin{array}{l}\text { Overall } \\
\text { risk of } \\
\text { bias }\end{array}$ \\
\hline $\begin{array}{l}\text { Uscher-Pines } \\
\text { (USA, 2016) }^{28}\end{array}$ & Serious & Moderate & Moderate & Serious & $\begin{array}{l}\text { No } \\
\text { available } \\
\text { information }\end{array}$ & Moderate & $\begin{array}{l}\text { No } \\
\text { available } \\
\text { information }\end{array}$ & Moderate \\
\hline $\begin{array}{l}\text { Gordon (USA, } \\
\text { 2017) }\end{array}$ & Serious & Moderate & Moderate & Moderate & $\begin{array}{l}\text { No } \\
\text { available } \\
\text { information }\end{array}$ & Moderate & $\begin{array}{l}\text { No } \\
\text { available } \\
\text { information }\end{array}$ & Moderate \\
\hline Shi (USA, 2018) 26 & Moderate & Serious & Moderate & Moderate & $\begin{array}{l}\text { No } \\
\text { available } \\
\text { information }\end{array}$ & Moderate & $\begin{array}{l}\text { No } \\
\text { available } \\
\text { information }\end{array}$ & Moderate \\
\hline $\begin{array}{l}\text { Davis (USA, } \\
\text { 2019)16 }\end{array}$ & Serious & Moderate & Moderate & Serious & $\begin{array}{l}\text { No } \\
\text { available } \\
\text { information }\end{array}$ & Moderate & $\begin{array}{l}\text { No } \\
\text { available } \\
\text { information }\end{array}$ & Serious \\
\hline $\begin{array}{l}\text { Halpren-Ruder } \\
\text { (USA, 2019) }^{18}\end{array}$ & Serious & Serious & Moderate & Moderate & $\begin{array}{l}\text { No } \\
\text { available } \\
\text { information }\end{array}$ & Moderate & $\begin{array}{l}\text { No } \\
\text { available } \\
\text { information }\end{array}$ & Moderate \\
\hline Ray (USA, 2019) ${ }^{25}$ & Moderate & Serious & Moderate & Moderate & $\begin{array}{l}\text { No } \\
\text { available } \\
\text { information }\end{array}$ & Moderate & $\begin{array}{l}\text { No } \\
\text { available } \\
\text { information }\end{array}$ & Moderate \\
\hline $\begin{array}{l}\text { Miller (USA, } \\
\text { 2020) }\end{array}$ & Serious & Moderate & Moderate & Serious & $\begin{array}{l}\text { No } \\
\text { available } \\
\text { information }\end{array}$ & Moderate & $\begin{array}{l}\text { No } \\
\text { available } \\
\text { information }\end{array}$ & Moderate \\
\hline $\begin{array}{l}\text { Murray (USA, } \\
2020)^{21}\end{array}$ & Serious & Serious & Moderate & Serious & $\begin{array}{l}\text { No } \\
\text { available } \\
\text { information }\end{array}$ & Moderate & $\begin{array}{l}\text { No } \\
\text { available } \\
\text { information }\end{array}$ & Serious \\
\hline $\begin{array}{l}\text { Penza (USA, } 2020 \\
\text { A) }\end{array}$ & Serious & Serious & Serious & Serious & $\begin{array}{l}\text { No } \\
\text { available } \\
\text { information }\end{array}$ & Moderate & $\begin{array}{l}\text { No } \\
\text { available } \\
\text { information }\end{array}$ & Serious \\
\hline $\begin{array}{l}\text { Penza (USA, } 2020 \\
\text { B) }\end{array}$ & Serious & Serious & Serious & Serious & $\begin{array}{l}\text { No } \\
\text { available } \\
\text { information }\end{array}$ & Moderate & $\begin{array}{l}\text { No } \\
\text { available } \\
\text { information }\end{array}$ & Serious \\
\hline $\begin{array}{l}\text { Stenehjem (USA, } \\
\text { 2020) }\end{array}$ & Serious & Serious & Moderate & Serious & Moderate & Moderate & $\begin{array}{l}\text { No } \\
\text { available } \\
\text { information }\end{array}$ & Moderate \\
\hline $\begin{array}{l}\text { Norden (USA, } \\
\text { 2020) }\end{array}$ & Serious & Serious & Serious & Serious & $\begin{array}{l}\text { No } \\
\text { available } \\
\text { information }\end{array}$ & Moderate & $\begin{array}{l}\text { No } \\
\text { available } \\
\text { information }\end{array}$ & Serious \\
\hline
\end{tabular}


Table 2. Diagnostic test performed

\begin{tabular}{|c|c|c|c|c|c|}
\hline Study ID & $\begin{array}{l}\text { Diagnostic tests } \\
\text { requested }\end{array}$ & Condition & $\begin{array}{l}\text { Telehealth } \\
\text { group } \\
\mathbf{N}(\%)\end{array}$ & $\begin{array}{l}\text { Face-to-face } \\
\text { group } \\
\mathbf{N}(\%)\end{array}$ & $\begin{array}{l}\text { Reported } P \\
\text { value }^{\text {a }}\end{array}$ \\
\hline \multicolumn{6}{|c|}{ Randomized controlled trial } \\
\hline \multirow[t]{3}{*}{$\begin{array}{l}\text { McKinstry (UK, } \\
2002)^{19}\end{array}$} & $\begin{array}{l}\text { Not specified blood } \\
\text { test }\end{array}$ & \multirow[t]{3}{*}{ All conditions } & $8(4 \%)$ & $10(5 \%)$ & \multirow[t]{3}{*}{ Not reported } \\
\hline & $\begin{array}{l}\text { Not specified urine } \\
\text { test }\end{array}$ & & $6(3 \%)$ & $8(4 \%)$ & \\
\hline & X-ray & & $1(0.6 \%)$ & $5(3 \%)$ & \\
\hline \multicolumn{6}{|c|}{ Cross-sectional studies } \\
\hline \multirow[t]{9}{*}{$\begin{array}{l}\text { Gordon (USA, } \\
\text { 2017) }\end{array}$} & \multirow[t]{4}{*}{$\begin{array}{l}\text { Not specified lab } \\
\text { tests }\end{array}$} & UTI & $85(20.6 \%)$ & $\begin{array}{l}1095 \\
(88.4 \%)\end{array}$ & $<0.001$ \\
\hline & & Pharyngitis & $45(15.8 \%)$ & $627(73.5 \%)$ & $<0.001$ \\
\hline & & Sinusitis & $185(11 \%)$ & $\begin{array}{l}1302 \\
(25.7 \%)\end{array}$ & $<0.001$ \\
\hline & & Bronchitis & $40(10.1 \%)$ & $308(25.8 \%)$ & $<0.001$ \\
\hline & \multirow{5}{*}{$\begin{array}{l}\text { Not specified } \\
\text { Imaging }\end{array}$} & Cough & $18(11.4)$ & $111(23.5)$ & 0.001 \\
\hline & & Bronchitis & $34(8.6 \%)$ & $212(17.8 \%)$ & $<0.001$ \\
\hline & & UTI & $34(8.2 \%)$ & $227(18.3 \%)$ & $<0.001$ \\
\hline & & URI & $69(8.1 \%)$ & $236(9.3 \%)$ & 0.31 \\
\hline & & Sinusitis & $90(5.3 \%)$ & $497(9.8 \%)$ & $<0.001$ \\
\hline \multirow{2}{*}{$\begin{array}{l}\text { Murray (USA, } \\
2020)^{21 ~ c}\end{array}$} & Urinalysis/dip stick & \multirow[t]{2}{*}{ UTI } & $8(5 \%)$ & $140(93 \%)$ & $<0.0001$ \\
\hline & Urine culture & & $11(7 \%)$ & $31(21 \%)$ & $<0.001$ \\
\hline \multirow{3}{*}{$\begin{array}{l}\text { Norden (USA, } \\
2020)^{22 ~ d ~}\end{array}$} & \multirow{3}{*}{$\begin{array}{l}\text { Not specified lab } \\
\text { tests }\end{array}$} & Pharyngitis & 0.125 & 0.207 & 0.55 \\
\hline & & $\begin{array}{l}\text { URI excluding } \\
\text { pharyngitis }\end{array}$ & 0.023 & 0.129 & 0.096 \\
\hline & & Otitis media & 0.250 & 0.107 & 0.60 \\
\hline $\begin{array}{l}\text { Ray (USA, } \\
2019)^{25} \\
\end{array}$ & Strep test & $\begin{array}{l}\text { Streptococcal } \\
\text { Pharyngitis } \\
\end{array}$ & $7(1 \%)$ & $10878(67 \%)$ & Not reported \\
\hline $\begin{array}{l}\text { Shi (USA, } \\
2018)^{26}\end{array}$ & Strep test & $\begin{array}{l}\text { Streptococcal } \\
\text { Pharyngitis }\end{array}$ & $9(4 \%)$ & $17818(68 \%)$ & Not reported \\
\hline \multicolumn{6}{|c|}{ UTI: Urinary tract infections, URI: Upper respiratory tract infections } \\
\hline \multicolumn{6}{|c|}{$\begin{array}{l}\text { a Chi-square test } \\
{ }^{b} \text { Tests were conducted within } 21 \text { days of index visit for all conditions } \\
{ }^{\mathrm{c}} \text { Tests were conducted at initial encounter } \\
{ }^{\mathrm{d}} \text { Average numbers of labs ordered }\end{array}$} \\
\hline
\end{tabular}


Table 3. Follow-up characteristics by initial encounter type

\begin{tabular}{|c|c|c|c|c|c|c|}
\hline \multirow[t]{2}{*}{ Study ID } & \multirow{2}{*}{$\begin{array}{l}\text { Follow-up visits } \\
\text { within }\end{array}$} & \multirow[t]{2}{*}{ Condition } & \multicolumn{2}{|l|}{ Telehealth group } & \multicolumn{2}{|l|}{ Face-to-face } \\
\hline & & & $\begin{array}{c}\text { Number of follow- } \\
\text { up visits }\end{array}$ & $\%$ & $\begin{array}{c}\text { Number of follow- } \\
\text { up visits }\end{array}$ & $\%$ \\
\hline \multirow{2}{*}{$\begin{array}{l}\text { Ray (USA, } \\
2019)^{25}\end{array}$} & 2 days & \multirow[t]{2}{*}{ ARI } & 226 & 5 & 5875 & 1 \\
\hline & 21 days & & 525 & 11 & 45629 & 9 \\
\hline \multirow{2}{*}{$\begin{array}{l}\text { Shi (USA, } \\
2018)^{26}\end{array}$} & 2 days & \multirow[t]{2}{*}{ ARI } & 1165 & 3 & 4713 & 0.5 \\
\hline & 21 days & & 3884 & 10 & 56557 & 6 \\
\hline $\begin{array}{l}\text { Gordon (USA, } \\
\text { 2017) }\end{array}$ & 21 days & $\begin{array}{l}\text { All } \\
\text { conditions }\end{array}$ & 1302 & 28 & 3900 & 28 \\
\hline \multirow[t]{2}{*}{$\begin{array}{l}\text { Murray (USA, } \\
2020)^{21}\end{array}$} & $\begin{array}{c}\text { Same day as } \\
\text { initial } \\
\text { encounter }\end{array}$ & \multirow[t]{2}{*}{ UTI } & 15 & 10 & 6 & 9 \\
\hline & 30 days & & 47 & 31 & 39 & 26 \\
\hline \multirow[t]{2}{*}{$\begin{array}{l}\text { Penza (USA, } \\
2020 \mathrm{~A})^{23}\end{array}$} & $\begin{array}{l}\text { Same day as } \\
\text { initial } \\
\text { encounter }\end{array}$ & \multirow[t]{2}{*}{ Sinusitis } & 26 & 49 & 1 & 5 \\
\hline & 30 days & & 53 & 35 & 21 & 14 \\
\hline $\begin{array}{l}\text { Penza (USA, } \\
2020 \text { B) }\end{array}$ & 14 days & Conjunctivitis & 92 & 46 & 15 & 7 \\
\hline \multirow{6}{*}{$\begin{array}{l}\text { Norden (USA, } \\
2020)^{22}\end{array}$} & \multirow[t]{3}{*}{ 1-day } & Pharyngitis & Not reported & 40 & \multirow[t]{3}{*}{ Not reported } & 21 \\
\hline & & ARI & & 7 & & 2 \\
\hline & & Otitis media & & 13 & & 7 \\
\hline & \multirow[t]{3}{*}{ 3-day } & Pharyngitis & Not reported & 53 & \multirow[t]{3}{*}{ Not reported } & 28 \\
\hline & & ARI & & 14 & & 9 \\
\hline & & Otitis media & & 13 & & 14 \\
\hline
\end{tabular}

